\title{
ANALISIS AMPLITUDE VERSUS OFFSET (AVO) MENGGUNAKAN PARAMETER PETROFISIKA LAMBDA MU RHO (LMR) DAN EXTENDED ELASTIC IMPEDANCE (EEI) UNTUK KARAKTERISASI RESERVOAR KARBONAT
}

\author{
Harsano Jayadi ${ }^{1}$, Icha Untari Meidji ${ }^{1}$, Yusniati H.Muh. Yusuf ${ }^{2}$ \\ ${ }^{1}$ Jurusan Teknik Geologi Universitas Tadulako, Palu \\ ${ }^{2}$ Jurusan pendidikan Fisika, Universitas Nusa Cendana, Kupang \\ E-mail: harsanoj@untad.ac.id
}

\begin{abstract}
The research that refers to the characterization of carbonate reservoir to identify lithology and fluid had been done to the Baturaja Formation in South Sumatera Basin. The method used is analyzed of Amplitude Versus Offset (AVO) by utilizing the petrophysics parameter of Lambda Mu Rho (LMR) and Extended Elastic Impedance (EEI). The goal of the research is to find out the comparison of the application of petrophysics parameter LMR and EEI to characterization carbonate reservoir, besides finding a prospect location or proposed well. The result of data analysis of Al-Fatah well shows that the carbonate reservoir position with liquefied gas is located deeper around 350 meters with a thickness of around 7.62 meters. Interpretation of seismic from inversion result by using the petrophysics parameter of LMR and EEI shows the presence of a prospect location to the CDP 4253 up to 4301, which is carbonate reservoir with fluid accumulation (gas).
\end{abstract}

Keywords: P Impedance, S Impedance, Lambda Rho, Mu Rho, Extended Elastic Impedance.

\section{PENDAHULUAN}

$\mathrm{P}$ ada awalnya penentuan titik bor pada eksplorasi hidrokarbon dilakukan dengan interpretasi geologi saja tetapi pada kenyataannya struktur geologi yang bagus belum tentu menentukan reservoar yang bagus sehingga diperlukan suatu metode untuk mengetahui karakterisasi reservoar dengan tujuan untuk mengurangi kesalahan dalam menentukan titik bor. Dalam kegiatan eksplorasi minyak dan gas bumi, karakterisasi reservoar merupakan tahapan yang penting, hal ini dikarenakan dalam melakukan suatu karakterisasi reservoar diperlukan suatu parameter fisika batuan untuk membedakan kontras impedansi dalam suatu lapisan batuan yang diakibatkan oleh perbedaan litologi dan fluida batuan yang berada di bawah permukaan (Jayadi, 2016).

Inversi data seismik post-stack untuk memperoleh penampang impedansi akustik merupakan salah satu cara untuk karakterisasi reservoar karena impedansi akustik bisa digunakan untuk prediksi litologi dan porositas batuan. Namun pada kenyataannya banyak proyek pengembangan sumur dari beberapa perusahaan migas (minyak dan gas bumi) yang gagal dengan menggunakan impedansi akustik. Hal tersebut disebabkan karena impedansi akustik hanya menggunakan kecepatan gelombang akustik dan sudut 
datang gelombang normal atau pada offset sama dengan nol (zero offset) (Goodway, Chen, \& Downton, 1997).

Seiring dengan perkembangan ilmu pengetahuan dan teknologi maka para ahli mencoba mengatasi kelemahan dari impedansi akustik yaitu dengan menggunakan data seismik pre-stack dalam bentuk gather dan kombinasi kecepatan gelombang $\mathrm{P}$, kecepatan gelombang $\mathrm{S}$ dan densitas. Hal tersebut dilakukan karena data seismik prestack memiliki jangkauan sudut yang bervariasi atau tidak pada offset sama dengan nol. Variasi amplitudo pada data seismik pre-stack lebih dikenal dengan istilah Amplitude Versus Offset (AVO). AVO sangat efektif untuk identifikasi litologi dan fluida pori. Analisis AVO menggunakan parameter petrofisika sampai saat ini banyak dikembangkan oleh para ahli untuk karakterisasi reservoar melalui teknik inversi AVO (Rutherford \& Williams, 1989). Hal serupa juga dilakukan penelitian yang dilakukan (Sumirah, 2007), untuk medeteksi adanya suatu reservoar gas pada daerah yang mempunyai litologi batupasir dengan menggabungkan analisis AVO dengan inversi Lamda Mu Rho (LMR) dan inversi simultan dan analisis LMR (Hermawan, 2010).

Parameter petrofisika yang sangat beperan dalam hal membedakan suatu reservoar untuk batuan pasir dengan litologi yang lain adalah paramer Lame (Harun, Sandria, Ilhami, Sukmatiawan, \& Razi, 2013). Parameter Lame' yaitu Lambda $\lambda$ merupakan inkompressibilitas sedangkan $\mathrm{Mu} \mu$ merupakan rigiditas. (Goodway et al., 1997), menyatakan bahwa Lambda Rho $(\lambda \rho)$ merupakan indikator fluida sedangkan $\mathrm{Mu}$ Rho $(\mu \rho)$ merupakan indikator litologi melalui analisis AVO menggunakan parameter petrofisika Lambda Mu Rho (LMR). Parameter LMR merupakan suatu besaran petrofisika yang mampu memisahkan antara litologi, hal ini dikarenakan adanya parameter Lame $(\lambda, \mu, \lambda / \mu)$ lebih sensitif daripada parameter kecepatan gelombang $\mathrm{P}$ $(\mathrm{Vp})$, kecepatan gelombang $\mathrm{S}(\mathrm{Vs})$ dan $\mathrm{Vp} / \mathrm{Vs}$.

Extended Elastic Impedance (EEI) ini merupakan pengembangan dari metode Elastic Impedance (EI) dan Acoustic Impedance (AI) (Whitcombe, Connolly, Reagan, \& Redshaw, 2002). Jangkauan sudut yang digunakan pada EEI lebih luas bila dibandingkan dengan jangkauan sudut pada EI. Sudut yang digunakan pada EEI merupakan sudut proyeksi sehingga keterbatasan sudut dari EI dapat diatasi dengan EEI. Jangkauan sudut proyeksi $(\chi)$ pada EEI adalah $-90^{\circ}$ sampai $+90^{\circ}$ sehingga korelasi dengan parameter petrofisika yang sensitif terhadap litologi dan fluida dapat dilakukan dengan menggunakan jangkauan sudut proyeksi $(\chi)$ yang tepat. Metode EEI dapat digunakan ketika metode $A I$ dan $E I$ tidak dapat membedakan litologi maupun fluida dengan baik akibat adanya ambiguitas nilai impedansi (Harun et al., 2013)

Hasil dari EEI ini dapat dipakai untuk mencari nilai sudut yang akan mewakili beberapa parameter petrofisika seperti rigiditas, densitas, inkompresibilitas, poison rasio, dan $\mathrm{Vp} / \mathrm{Vs}$ yang terdapat pada sumur sehingga mampu mendapatkan model persebaran dan karakteristik dari paramter tersebut secara lateral (Connolly, 2010).

\section{METODE PENELITIAN}

Data yang digunakan dalam penelitian ini adalah : Satu lintasan data seismik 2D dengan arah NW dan SE dalam bentuk CDP gather PSTM (Pre-Stack Time Migration) dengan format sgy. Selain itu digunakan juga beberapa data log yang diperoleh dari satu sumur yaitu : log sonik, log densitas, log gamma ray, log NPHI, log Resistivitas dan parameter water saturation $(\mathrm{Sw})$. Ada 5 tahapan yang dilakukan dalam penelitian ini, 
diantaranya sebagai berikut:

1. Pengolahan data $\log$ sumur berupa $\log$ impedansi $P\left(Z_{p}\right), \log$ impedansi $S\left(Z_{s}\right), \log$ Lambda Rho ( $\lambda . \rho)$ dan log Mu Rho ( $\mu . \rho)$ dengan menggunakan Transform yang ada pada program eLog dengan input yang digunakan adalah data $\log$ sonik (log $\mathrm{V}_{\mathrm{p}}$ dan $\log \mathrm{V}_{\mathrm{s}}$ ), dan $\log$ densitas $(\rho)$. Data $\log$ sonik $\left(\log \mathrm{V}_{\mathrm{p}}\right.$ dan $\left.\log \mathrm{V}_{\mathrm{s}}\right)$, dan $\log$ densitas $(\rho)$ digunakan juga untuk membuat log EEI dengan jangkauan sudut chi $\chi=-90^{\circ}$ sampai $\chi=+90^{\circ}$ dengan menggunakan software Ms Excel. Selanjutnya dilakukan analisis log EEI untuk menentukan sudut chi $(\chi)$ melalui korelasi log EEI dengan log yang sensitif terhadap litologi dan fluida yaitu $: \log Z_{\mathrm{p}}, \log Z_{\mathrm{s}}, \log \lambda . \rho$ dan $\log \mu . \rho$. Interpretasi data log dilakukan melalui crossplot untuk mengetahui sensitifitas parameter petrofisika yaitu $: \log \mathrm{Z}_{\mathrm{p}}, \log \mathrm{Z}_{\mathrm{s}}, \log \lambda . \rho, \log \mu . \rho$ dan $\log$ EEI terhadap litologi dan fluida. Selain itu juga untuk menentukan nilai batas (cut off) untuk masing-masing parameter tersebut.

2. Melakukan import data seismik dilakukan pada data seismik 2D PSTM (pre-stack time migration) gather dalam format sgy yang akan ditampilkan dalam bentuk CDP (common depth point) gather dengan domain offset. Kemudian dilakukan proses super gather untuk memperkuat signal dan angle gather untuk mengubah domain offset menjadi domain sudut. Data seismik angle gather digunakan untuk membuat atribut AVO yaitu reflektivitas $\mathrm{P}$ dan reflektivitas $\mathrm{S}$ selain itu juga digunakan untuk membuat penampang seismik full stack. Sedangkan data seismik super gather digunakan untuk membuat penampang seismik near angle stack dan far angle stack. Penampang seismik near angle stack dan far angle stack digunakan untuk membuat penampang intercept (A) dan gradient (B). Kemudian dibuat penampang reflektivitas EEI melalui kombinasi antara intercept (A) dan Gradient (B) dengan menggunakan sudut $(\chi)$ tertentu yang diperoleh dari analisa log EEI.

3. Pengikatan data seismik dengan data sumur dilakukan untuk memposisikan horizon seismik dengan zona target data sumur. Proses yang dilakukan pada well to seismic tie adalah pencocokan antara seismogram sintetik dengan trace data seismik lapangan. Wavelet yang digunakan untuk membuat seismiogram sintetik diekstraksi dari dari penampang seismik full stack. Proses pengikatan data seismik dengan data sumur dilakukan berulang-ulang hingga diperoleh nilai korelasi yang baik.

4. Melakukan inversi untuk penampang Lambda $\mathrm{Mu}$ Rho dengan metode analisis Linear Programming Sparse Spike (LPSS) serta inversi data seismik untuk menghasilkan penampang EEI yang sensitif terhadap litologi dan fluida.

5. Analisis penampang hasil inversi untuk mengetahui penyebaran litologi dan fluida secara lateral dilakukan pada penampang berikut : Penampang $\mathrm{Z}_{\mathrm{p}}$, Penampang $\mathrm{Z}_{\mathrm{s}}$, penampang Lambda Rho, Penampang Mu Rho, Penampang EEI sudut $\chi=0^{0}$, Penampang EEI sudut $\chi=15^{\circ}$, Penampang EEI sudut $\chi=-30^{\circ}$, Penampang EEI sudut $\chi=-50^{\circ}$. Interpretasi secara kuantitatif dilakukan dengan menggunakan nilai batas (cut off) yang diperoleh dari hasil crossplot data sumur.

\section{HASIL DAN PEMBAHASAN}

\section{A. Hasil}

Lokasi penelitian ini diberi nama lapangan $X$ untuk menjaga kerahasiaan lokasi sebenarnya dan berada di cekungan Sumatera Selatan dengan kandungan hidrokarbon berupa gas (Gambar 1). 


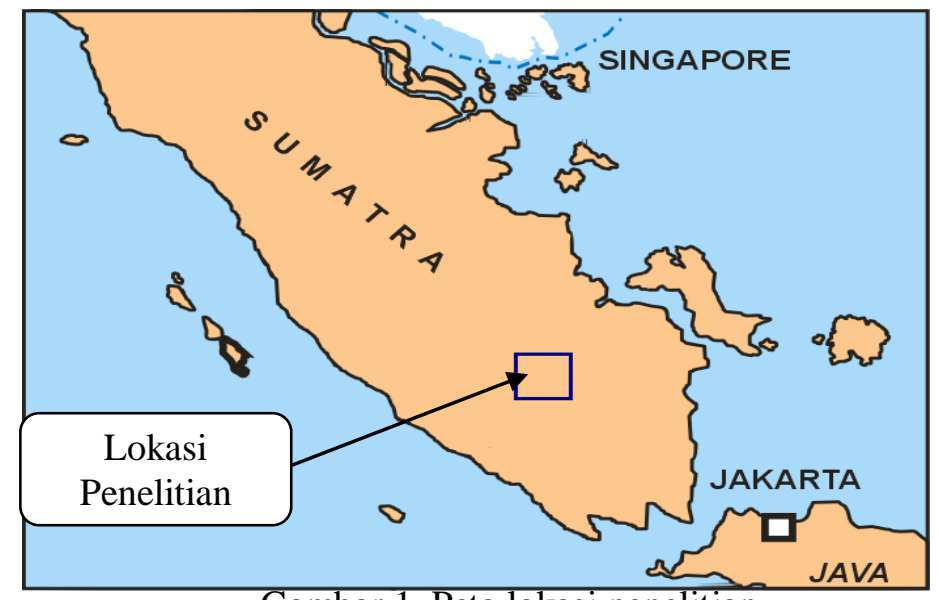

Gambar 1. Peta lokasi penelitian

Lokasi penelitian ini cekungan Sumatra Selatan, Formasi Baturaja dengan geologi regionalnya merupakan perkembangan umur Pra-Tersier, perkembangan Awal Tersier dan perkembangan Akhir Tersier. Secara stratigrafis cekungan Sumatra Selatan tersusun dari formasi yang tertua berupa batuan Pra-Tersier, kemudian diikuti oleh Tuff Kikim dan batuan Tuff lainnya. Formasi Lemat / Lahat terdiri atas "Granit wash", endapan alluvial / fluvial, anggota serpih Benakat, formasi Talang Akar, formasi Batu Raja, formasi Telisa, dan yang paling muda adalah formasi Palembang (Aina, 2017)

Nilai GR min = 13 API pada gambar di atas merupakan nilai terendah dari log GR yang menunjukkan gamping dan nilai GR max $=71$ API merupakan nilai tertinggi GR yang menunjukkan shale. Nilai GR cut off $=42$ API (Gambar 2). Persentase serpih (Vsh) dalam batuan diambil sebesar $50 \%$ berdasarkan perkiraan dari jumlah total yaitu $100 \%$. Berikut ini adalah perhitungan GR cutt off.

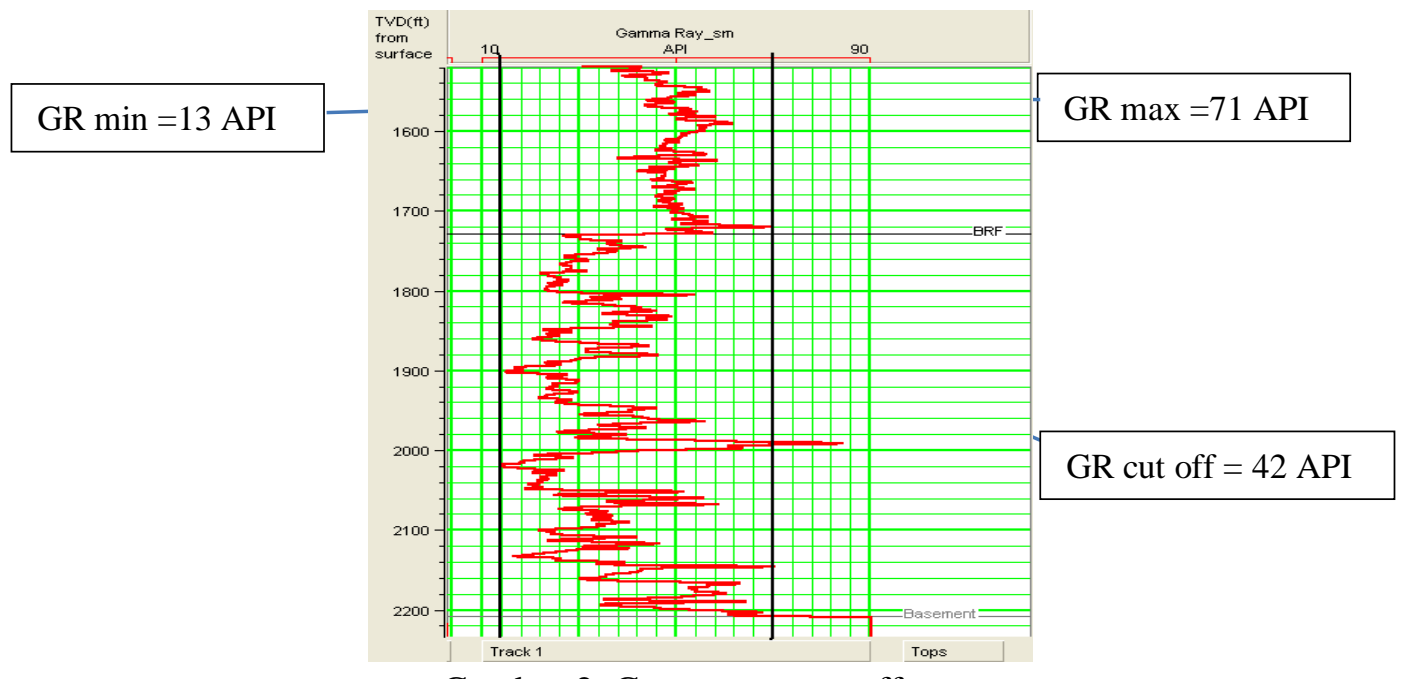

Gambar 2. Gamma ray cut off

Log EEI dibuat dengan menggunakan persamaan 2.64. Jangkauan sudut chi $(\chi)$ yang digunakan adalah $-90^{\circ}$ sampai $+90^{\circ}$ dengan kelipatan sudut chi $(\chi) 5^{0}$ seperti berikut : $-90^{0},-85^{\circ},-80, \ldots . .,+90^{\circ}$. Nilai konstanta $\mathrm{K}$ yang digunakan adalah 0.25 yang diperoleh dari daerah target. Grafik korelasi log EEI dengan parameter berikut : impedansi $\mathrm{P}\left(\mathrm{Z}_{\mathrm{p}}\right)$, impedansi-S $\left(\mathrm{Z}_{\mathrm{s}}\right)$, Lambda Rho $(\lambda . \rho)$ dan Mu Rho $(\mu . \rho)$ dapat dilihat 
pada Gambar 3 di bawah ini.

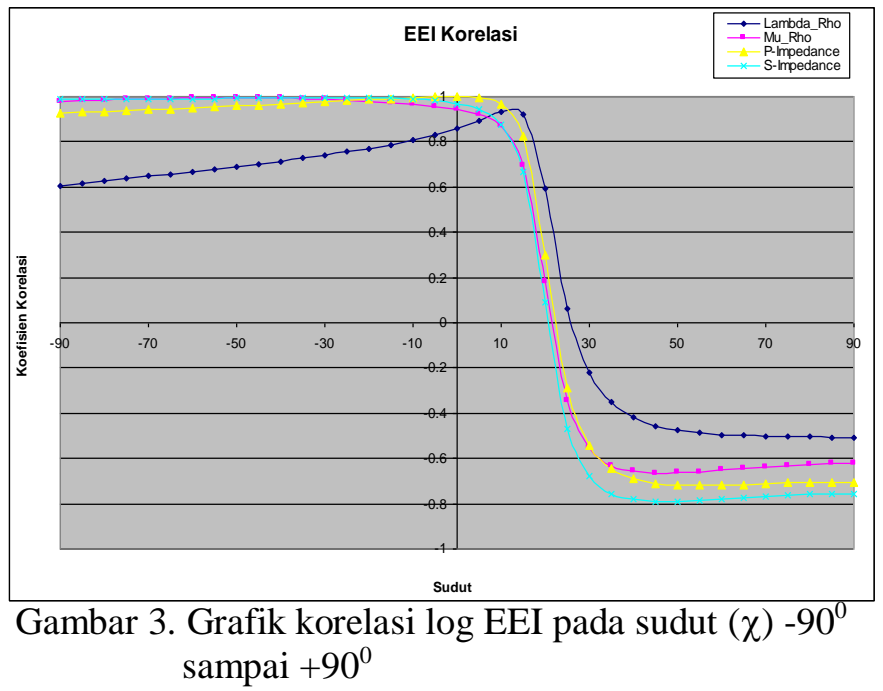

Nilai koefisien korelasi maksimum dan sudut chi $(\chi)$ yang diperoleh dari grafik korelasi log EEI (Gambar 4) di atas dapat dilihat pada tabel di bawah.

Tabel 1. Korelasi beberapa log dengan sudutnya

\begin{tabular}{lcc}
\multicolumn{1}{c}{ Tipe Log } & Koefisien Korelasi & Sudut Chi $(\chi)$ \\
\hline Impedansi-P & 1 & 0 \\
\hline Impedansi-S & 0.9955 & -30 \\
\hline Lambda Rho & 0.9348 & 15 \\
\hline Mu Rho & 0.9909 & -50 \\
\hline
\end{tabular}

\section{B. Pembahasan}

Interpretasi data sumur dilakukan melalui analisis data log sumur untuk mengetahui jenis litologi, fluida dan ketebalan reservoar secara vertikal pada suatu sumur. Beberapa log yang digunakan untuk interpretasi dalam penelitian ini adalah log gamma ray, log densitas, log sonik, log neutron (NPHI) dan log resistivitas.

Penentuan jenis litologi dengan menggunakan log gamma ray dapat diketahui jenis fluida pori adalah gas (Gambar 5). Hal tersebut ditunjukkan dengan adanya separasi yang relatif besar antara log densitas dengan neutron. Kemudian terlihat pula adanya penurunan kurva saturasi air, penurunan respon log kecepatan akustik $\left(\mathrm{V}_{\mathrm{p}}\right)$ secara drastis dan peningkatan respon log resistivitas menunjukkan bahwa reservoar tersebut mengandung hidrokarbon (gas). Berdasarkan respon data sumur tersebut maka dapat diketahui bahwa reservoar gas memiliki ketebalan sekitar 7.62 meter. 


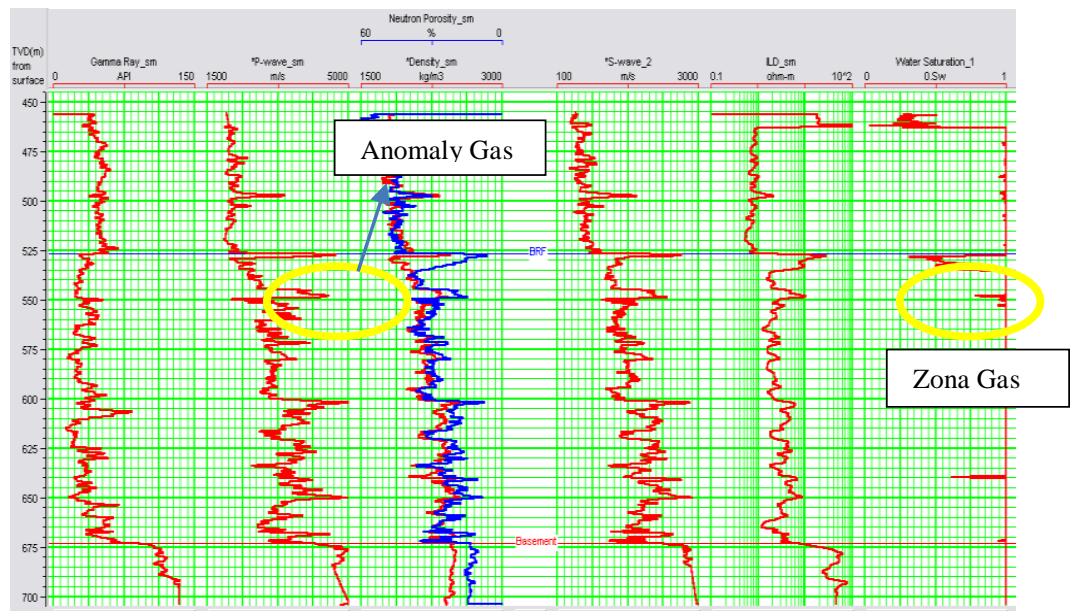

Gambar 5. Tampilan respon data log sumur

Untuk meningkatkan hasil interpretasi maka dilakukan crossplot data sumur dengan menggunakan atribut warna saturasi air ( $\mathrm{Sw}$ ) dan log gamma ray (GR). Nilai saturasi air yang tinggi (mendekati 1) menunjukkan bahwa reservoar lebih banyak terisi oleh air dari pada hidrokarbon.

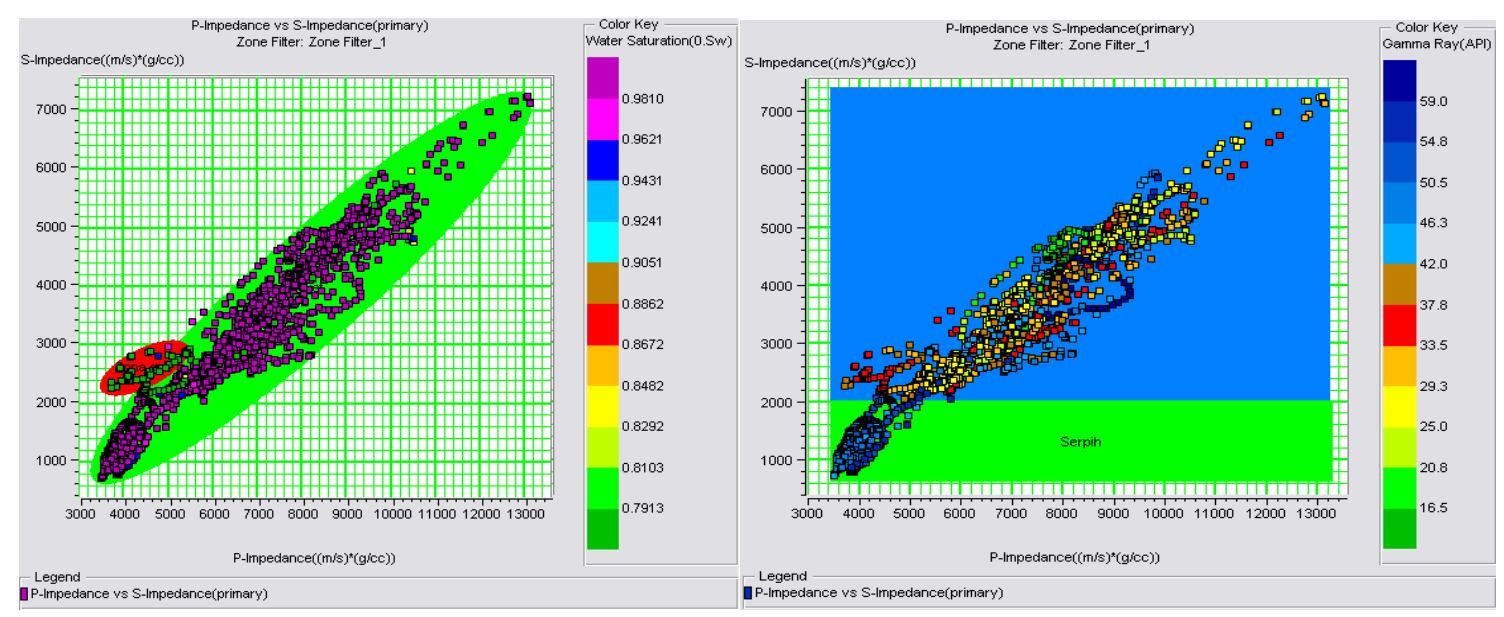

Gambar 6. (a) Crossplot log impedansi $\mathrm{p}\left(\mathrm{Z}_{\mathrm{p}}\right)$ dengan log impedansi s $\left(\mathrm{Z}_{\mathrm{s}}\right)$ dan (b) Crossplot log impedansi $\mathrm{p}\left(\mathrm{Z}_{\mathrm{p}}\right)$ dengan log impedansi $\mathrm{s}\left(\mathrm{Z}_{\mathrm{s}}\right)$

Crossplot $\log \mathrm{Z}_{\mathrm{p}}$ dengan $\log \mathrm{Z}_{\mathrm{s}}$ pada (Gambar 6.a) dilakukan dengan menggunakan atribut warna saturasi air $(\mathrm{Sw})$. Nilai saturasi air yang mendekati 0 disebut sebagai saturasi air rendah atau zona gas yang ditunjukkan oleh elips warna merah. Sedangkan nilai saturasi air yang mendekati 1 disebut sebagai saturasi air tinggi atau zona basah yang ditunjukkan oleh elips warna hijau. Berdasarkan pembagian zona gas dan basah tersebut diketahui bahwa $\log Z_{p}$ kurang efektif untuk identifikasi fluida (gas) karena terdapat overlap nilai impedansi $P$ antara serpih dan gas dari $36 \times 10^{5}$ sampai $56 \times 10^{5}\left(\mathrm{~kg} \cdot \mathrm{m}^{-2} \cdot \mathrm{s}^{-1}\right)$. Pada crossplot $\log \mathrm{Z}_{\mathrm{p}}$ dengan $\log \mathrm{Z}_{\mathrm{s}}$ digunakan juga atribut warna gamma ray untuk melihat sensitifitas $\log Z_{\mathrm{s}}$ dalam identifikasi litologi serpih dan gamping (Gambar 6.b). Nilai gamma ray di atas 42 API menunjukkan serpih dan nilai gamma ray di bawah 42 API menunjukkan gamping. Sehingga dapat diperoleh nilai batas impedansi S untuk serpih dan gamping yaitu $2 \times 10^{6}\left(\mathrm{~kg} \cdot \mathrm{m}^{-2} \cdot \mathrm{s}^{-1}\right)$. Berdasarkan nilai batas tersebut maka $\log \mathrm{Z}_{\mathrm{s}}$ dapat dikatakan sensitif dalam identifikasi litologi. 

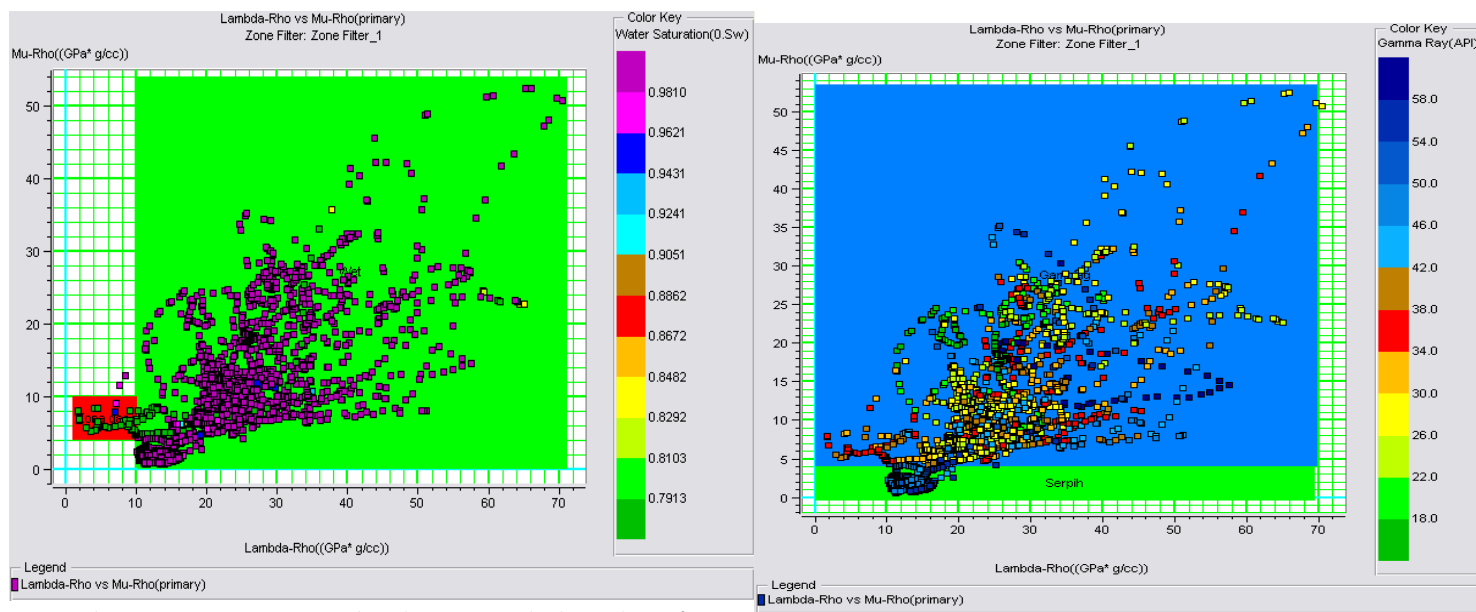

Gambar 7. (a) Crossplot log Lambda Rho ( $\lambda . \rho)$ dengan log Mu Rho ( $\mu . \rho)$ dan (b) Crossplot log

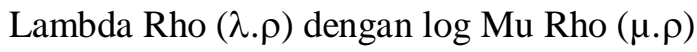

Atribut warna yang digunakan pada crossplot log $\lambda . \rho$ dengan log $\mu . \rho$ di (Gambar 7.a) adalah saturasi air. Berdasarkan atribut warna saturasi air diperoleh zona gas dengan nilai saturasi air mendekati nol dan zona basah dengan nilai saturasi air mendekati 1. Pada crossplot ini log $\lambda . \rho$ termasuk efektif dalam identifikasi fluida (gas) karena nilai batas $\lambda . \rho$ untuk zona basah dan gas dapat ditentukan yaitu sebesar $10 \times 10^{13}$ $(\mathrm{Pa})\left(\mathrm{kg} / \mathrm{m}^{3}\right)$. Walaupun sebagian zona basah dan zona gas masih terlihat overlap. Crossplot $\log \lambda . \rho$ dengan $\log \mu . \rho$ (Gambar 7.b) menggunakan atribut warna gamma ray untuk melihat sensitifitas $\log \mu$. $\rho$ terhadap litologi. Berdasarkan nilai batas gamma ray sebesar 42 API diketahui bahwa log $\mu$. $\rho$ termasuk indikator litologi yang baik karena terjadi separasi antara serpih dan gamping. Nilai gamma ray di atas 42 API menunjukkan serpih dan nilai gamma ray di bawah 42 API merupakan gamping. Nilai batas $\mu . \rho$ antara serpih dan gamping diambil sebesar $4 \times 10^{12}(\mathrm{~Pa})\left(\mathrm{kg} / \mathrm{m}^{3}\right)$.
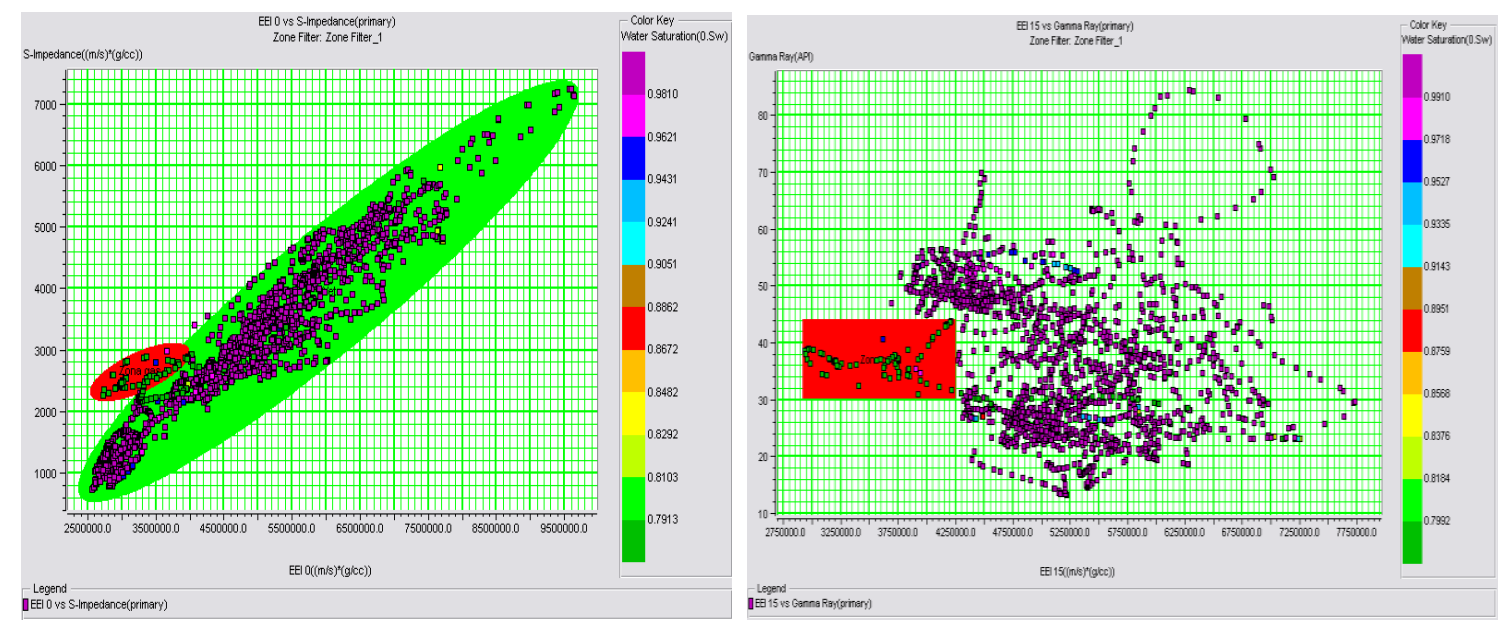

Gambar 8. (a) Crossplot log EEI $\left(\chi=0^{\circ}\right)$ dengan log impedansi s $\left(\mathrm{Z}_{\mathrm{s}}\right)$ dan (b) Crossplot log EEI $\left(\chi=15^{\circ}\right)$ dengan log gamma ray

Crossplot log EEI $\left(0^{0}\right)$ dengan log impedansi $S\left(Z_{s}\right)$ pada (Gambar 8.a) menggunakan atribut warna saturasi air untuk mengetahui sensitifitas log EEI $\left(0^{0}\right)$ terhadap fluida. Nilai saturasi air mendekati 1 merupakan zona basah (elips warna hijau) 
sedangkan nilai saturasi mendekati 0 merupakan zona gas (elips warna merah). Berdasarkan analisis tersebut maka dapat diketahui bahwa log EEI $\left(0^{0}\right)$ tidak efektif dalam identifikasi fluida. Hal tersebut disebabkan karena zona basah (wet) dan zona gas berada pada nilai impedansi yang relatif sama yaitu $27 \times 10^{+8}$ sampai $4 \times 10^{+8}\left(\mathrm{~kg} \cdot \mathrm{m}^{-2} \cdot \mathrm{s}^{-1}\right)$. Crossplot log EEI $\left(15^{0}\right)$ dengan log gamma ray dilakukan dengan menggunakan atribut warna saturasi air untuk mengetahui sensitifitas log EEI $\left(15^{0}\right)$ terhadap fluida. Pada (Gambar 8.b) daerah kotak warna merah merupakan zona gas karena memiliki nilai saturasi air yang rendah yaitu mendekati nol sehingga dapat dikatakan bahwa log EEI $\left(15^{0}\right)$ sensitif terhadap fluida pori bila dibandingkan dengan log EEI $\left(0^{0}\right)$. Nilai batas zona gas pada log EEI $\left(15^{0}\right)$ adalah sekitar $29 \times 10^{+8}$ sampai $425 \times 10^{+7}\left(\mathrm{~kg} \cdot \mathrm{m}^{-2} \cdot \mathrm{s}^{-1}\right)$.
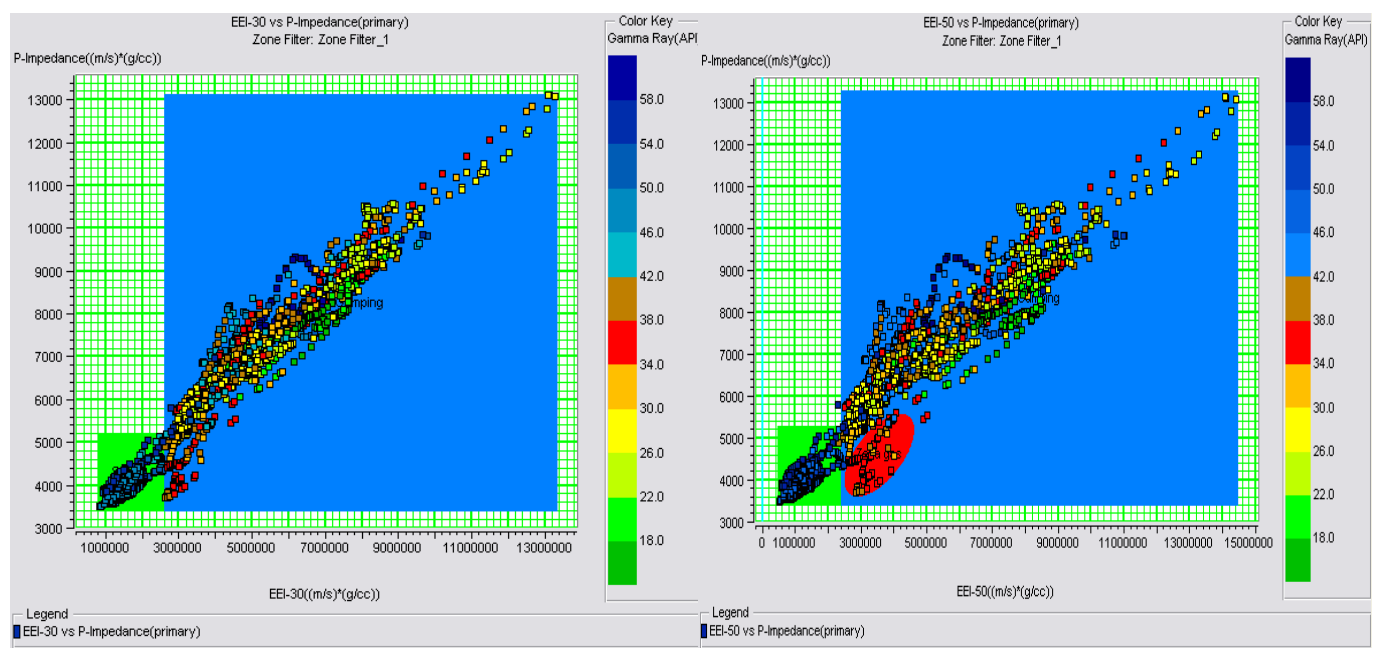

Gambar 9. (a) Crossplot $\log$ EEI $\left(\chi=-30^{\circ}\right)$ dengan log impedansi $\mathrm{p}\left(\mathrm{Z}_{\mathrm{p}}\right)$ dan (b) Crossplot $\log \operatorname{EEI}\left(\chi=-50^{0}\right)$ dengan log impedansi $\mathrm{p}\left(\mathrm{Z}_{\mathrm{p}}\right)$

Hasil inversi parameter petrofisika Lambda Mu Rho (LMR) dan Extended Elastic Impedance (EEI) diharapkan mampu meningkatkan kualitas interpretasi seperti identifikasi litologi dan fluida pori (gas). Hasil analisis crossplot data sumur yang telah dilakukan dijadikan acuan dalam identifikasi sebaran litologi dan fluida pori secara lateral pada penampang seismik (Lampiran).

Penampang impedansi $\mathrm{P}$, yang terdapat pada lampiran (Gambar 10) mempunyai nilai impedansi $\mathrm{P}$ terendah $265 \times 10^{4}\left(\mathrm{~kg} \cdot \mathrm{m}^{-2} \cdot \mathrm{s}^{-1}\right)$ yang ditunjukkan dengan warna hijau dan nilai impedansi tertinggi $87 \times 10^{5}\left(\mathrm{~kg} \cdot \mathrm{m}^{-2} \cdot \mathrm{s}^{-1}\right)$ yang ditunjukkan dengan warna ungu. Berdasarkan hasil crossplot $\log \mathrm{Z}_{\mathrm{p}}$ diketahui bahwa parameter impedansi $\mathrm{P}$ tidak efektif untuk identifikasi fluida karena antara serpih dan anomali gas berada pada nilai impedansi yang sama yaitu sekitar $36 \times 10^{5}$ sampai $56 \times 10^{5}\left(\mathrm{~kg} \cdot \mathrm{m}^{-2} \cdot \mathrm{s}^{-1}\right)$. Pada penampang impedansi $\mathrm{P}$ nilai tersebut ditunjukkan dengan warna hijau kekuningan sampai merah merah yang berada pada bagian atas reff (terumbu) di sekitar waktu 600 ms. Identifikasi gas pada daerah tersebut belum dapat dipastikan dengan jelas karena pada daerah sekitar sumur (CDP 4221) bisa saja menunjukkan serpih atau zona dengan porositas yang tinggi.

Identifikasi litologi serpih dan gamping dilakukan pada penampang impedansi $\mathrm{S}$, yang terdapat pada lampiran (Gambar 11). Serpih ditunjukkan dengan warna hijau dengan nilai sekitar $924 \times 10^{3}$ sampai $2002 \times 10^{3}\left(\mathrm{~kg} \cdot \mathrm{m}^{-2} \cdot \mathrm{s}^{-1}\right)$ sedangkan gamping ditunjukkan dengan warna kuning sampai ungu dengan nilai $\mathrm{Zs}$ di atas $2002 \times 10^{3}$ (kg.m ${ }^{-}$ 
$\left.{ }^{2} \cdot \mathrm{s}^{-1}\right)$. Warna merah dan kuning menunjukkan daerah poros dan penyebarannya secara lateral ke arah SE dan NW. Daerah yang memiliki rigiditas tinggi umumnya berada di bagian bawah pada Formasi Baturaja. Gamping yang rigiditasnya besar didentifikasi sebagai platform dari reff dan ditunjukkan dengan warna ungu. Hal tersebut juga didukung dengan data geologi regionalnya. Daerah prospek ditunjukkan dengan lingkaran hitam.

Penampang Lambda Rho ( $\lambda . \rho)$, yang terdapat pada lampiran (Gambar 13) memiliki jangkauan nilai Lambda Rho 0 sampai $343 \times 10^{11}(\mathrm{~Pa})\left(\mathrm{kg} / \mathrm{m}^{3}\right)$ yang ditunjukkan dengan warna hijau kekuningan sampai warna ungu. Identifikasi fluida dilakukan berdasarkan hasil analisis crossplot log Lambda Rho yang menunjukkan bahwa inkompressibilitas yang rendah sekitar 0 sampai $1 \times 10^{13}(\mathrm{~Pa})\left(\mathrm{kg} / \mathrm{m}^{3}\right)$ (warna hijau) merupakan gas. Daerah potensial baru pada penampang Lambda Rho ditunjukkan dengan garis kotak warna hitam. Daerah tersebut merupakan reservoar karbonat dengan fluida pori gas karena memiliki inkompressibilitas rendah yaitu di bawah $1 \times 10^{13}$ $(\mathrm{Pa})\left(\mathrm{kg} / \mathrm{m}^{3}\right)$. Inkompressibilitas yang rendah juga terlihat pada sumur XX yang ditandai dengan lingkaran warna hitam.

Parameter petrofisika Mu Rho ( $\mu . \rho)$ merupakan diskriminator litologi sehingga penampang $\mathrm{Mu}$ Rho, yang terdapat pada lampiran (Gambar 14) digunakan untuk identifikasi serpih dan gamping. Nilai terendah pada penampang Mu Rho tersebut adalah 0 sedangkan nilai tertingginya $188 \times 10^{11}(\mathrm{~Pa})\left(\mathrm{kg} / \mathrm{m}^{3}\right)$. Nilai batas (cut off) untuk serpih dan gamping adalah $4 \times 10^{12}(\mathrm{~Pa})\left(\mathrm{kg} / \mathrm{m}^{3}\right)$ berdasarkan hasil crossplot log Mu Rho. Pada penampang Mu Rho warna kuning sampai ungu merupakan gamping sedangkan warna hijau kekuningan sampai warna hijau merupakan serpih. Platform reff pada formasi baturaja ditunjukkan dengan rigiditas yang besar (warna ungu). Untuk memperkuat hasil interpretasi maka dilakukan crossplot antara penampang Lambda Rho dan Mu Rho hasil inversi yang ditunjukkan di lampiran (Gambar 15).

Penampang EEI $\left(0^{0}\right)$ yang terdapat pada lampiran (Gambar 16) mempunyai nilai EEI $21 \times 10^{8}$ sampai $647 \times 10^{7}\left(\mathrm{~kg} \cdot \mathrm{m}^{-2} \cdot \mathrm{s}^{-1}\right)$ yang ditunjukkan dengan warna hijau sampai warna ungu. Interpretasi penampang EEI $\left(0^{0}\right)$ sulit dilakukan karena serpih (shale) dan karbonat poros (reservoar gas) berada pada nilai EEI yang sama yaitu sekitar $26 \times 10^{8}$ sampai $42 \times 10^{8}\left(\mathrm{~kg} \cdot \mathrm{m}^{-2} \cdot \mathrm{s}^{-1}\right)$. Walaupun pada penampang EEI $\left(0^{0}\right)$ efek fluida pori (gas) tidak muncul identifikasi litologi masih dapat dilakukan karena nilai EEI $\left(0^{0}\right)$ di atas $42 \times 10^{8}\left(\mathrm{~kg} \cdot \mathrm{m}^{-2} . \mathrm{s}^{-1}\right)$ menunjukkan karbonat. Sedangkan serpih yang memiliki nilai EEI $\left(0^{0}\right)$ di bawah $26 \times 10^{8}\left(\mathrm{~kg} \cdot \mathrm{m}^{-2} \cdot \mathrm{s}^{-1}\right)$ masih bisa dideteksi dan berada pada bagian atas formasi baturaja yang ditunjukkan dengan warna hijau.

Analisis crossplot menunjukkan bahwa log EEI $\left(15^{0}\right)$ memiliki sensitifitas yang baik untuk identifikasi fluida pori (gas). Penampang EEI $\left(15^{\circ}\right)$, yang ditunjukkan pada lampiran (Gambar 17) memiliki nilai terendah $359 \times 10^{7}\left(\mathrm{~kg} . \mathrm{m}^{-2} \cdot \mathrm{s}^{-1}\right)$ yang ditunjukkan dengan warna hijau dan nilai EEI tertinggi $585 \times 10^{7}\left(\mathrm{~kg} \cdot \mathrm{m}^{-2} \cdot \mathrm{s}^{-1}\right)$ yang ditunjukkan dengan warna ungu. Pada penampang EEI $\left(15^{0}\right)$ fluida pori (gas) ditunjukkan dengan warna hijau atau pada nilai $359 \times 10^{7}$ sampai $395 \times 10^{7}\left(\mathrm{~kg} \cdot \mathrm{m}^{-2} \cdot \mathrm{s}^{-1}\right)$. Penyebaran daerah potensial atau reservoar karbonat yang terisi gas berada pada arah NW yang ditunjukkan dengan garis kotak warna hitam sedangkan pada sumur XX juga terlihat adanya akumulasi gas yang ditunjukkan dengan lingkaran warna hitam.

Penampang EEI $\left(-30^{0}\right)$, yang terdapat pada lampiran (Gambar 18) memiliki nilai EEI $2 \times 10^{8}$ sampai $71 \times 10^{8}\left(\mathrm{~kg} . \mathrm{m}^{-2} . \mathrm{s}^{-1}\right)$ yang ditunjukkan dengan warna hijau sampai warna ungu. Hasil analisis log EEI pada sub bab IV.2.1.5 digunakan untuk membantu identifikasi litologi serpih dan gamping pada penampang EEI $\left(-30^{\circ}\right)$. Serpih 
pada penampang EEI $\left(-30^{0}\right)$ ditunjukkan oleh warna hijau kekuningan sampai warna hijau dengan nilai EEI $2 \times 10^{8}$ sampai $227 \times 10^{7}\left(\mathrm{~kg} \cdot \mathrm{m}^{-2} \cdot \mathrm{s}^{-1}\right)$ sedangkan gamping ditunjukkan dengan warna kuning sampai warna ungu dengan nilai di atas $227 \times 10^{7}$ $\left(\mathrm{kg} \cdot \mathrm{m}^{-2} \cdot \mathrm{s}^{-1}\right)$. Berdasarkan analisis tersebut diketahui bahwa penampang EEI $\left(-30^{0}\right)$ efektif untuk determinasi serpih dan gamping pada formasi Baturaja. Hasil interpretasi tersebut juga menunjukkan bahwa daerah yang relatif memiliki porositas yang tinggi berada pada bagian atas dari formasi Baturaja dengan penyebaran ke arah NW dan SE. Sedangkan bagian bawah dari formasi Baturaja relatif memiliki porositas yang rendah. Daerah prospek dengan porositas yang tinggi ditunjukkan dengan lingkaran warna hitam.

Penampang EEI $\left(-50^{\circ}\right)$, yang ditunjukkan pada lampiran (Gambar 19) memiliki nilai EEI $15 \times 10^{7}$ sampai $72 \times 10^{8}\left(\mathrm{~kg} \cdot \mathrm{m}^{-2} \cdot \mathrm{s}^{-1}\right)$ yang ditunjukkan dengan warna hijau sampai warna ungu. Nilai batas EEI $\left(-50^{0}\right)$ untuk serpih dan gamping diambil sebesar $224 \times 10^{+7}\left(\mathrm{~kg} \cdot \mathrm{m}^{-2} \cdot \mathrm{s}^{-1}\right)$. Untuk nilai di bawah $224 \times 10^{+7}\left(\mathrm{~kg} \cdot \mathrm{m}^{-2} \cdot \mathrm{s}^{-1}\right)$ merupakan serpih yang ditunjukkan dengan warna hijau kekuningan sampai warna hijau. Sedangkan nilai di atas $224 \times 10^{+7}\left(\mathrm{~kg} \cdot \mathrm{m}^{-2} \cdot \mathrm{s}^{-1}\right)$ merupakan gamping yang ditunjukkan dengan warna kuning sampai warna ungu. Berdasarkan hasil interpretasi penampang EEI $\left(-50^{0}\right)$ tersebut dapat diketahui bagian atas dari formasi Baturaja relatif lebih poros atau memiliki porositas yang tinggi bila dibandingkan dengan bagian bawah dari formasi Baturaja. Penyebaran daerah poros secara lateral terlihat berada pada arah NW dan SE. Daerah prospek dengan porositas yang tinggi ditunjukkan dengan lingkaran warna hitam.

\section{KESIMPULAN}

Reservoar karbonat pada formasi baturaja berada pada kedalaman sekitar 530 meter dengan ketebalan sekitar 7.62 meter. Sedangkan sensitifitas parameter petrofisika LMR dan EEI dapat diuraikan bahwa Parameter Lambda Rho dan EEI $\left(15^{0}\right)$ merupakan indikator fluida yang baik dengan nilai batas yang diperoleh pada Lambda Rho adalah 0 sampai $10 \times 10^{13}(\mathrm{~Pa})\left(\mathrm{kg} / \mathrm{m}^{3}\right)$ dan nilai batas yang diperoleh pada EEI $\left(15^{0}\right)$ adalah $29 \times 10^{8}$ sampai $425 \times 10^{7}\left(\mathrm{~kg} \cdot \mathrm{m}^{-2} \cdot \mathrm{s}^{-1}\right)$. Impedansi P dan EEI $\left(0^{0}\right)$ kurang sensitif terhadap kehadiran gas sehingga merupakan indikator fluida yang kurang baik. Hal tersebut disebabkan karena terjadi tumpang tindih (overlap) nilai impedansi $\mathrm{P}$ antara serpih dengan gas yaitu pada $36 \times 10^{5}$ sampai $56 \times 10^{5}\left(\mathrm{~kg} \cdot \mathrm{m}^{-2} \cdot \mathrm{s}^{-1}\right)$ sedangkan pada EEI $\left(0^{0}\right)$ serpih dan gas berada pada nilai yang sama yaitu $27 \times 10^{8}$ sampai $4 \times 10^{8} \quad\left(\mathrm{~kg} \cdot \mathrm{m}^{-2} \cdot \mathrm{s}^{-1}\right)$. Parameter $\mathrm{Mu}$ Rho dan EEI $\left(-50^{0}\right)$ merupakan indikator litologi yang baik. Determinasi serpih dan gamping pada $\mathrm{Mu}$ Rho berada pada nilai batas $4 \times 10^{12}(\mathrm{~Pa})\left(\mathrm{kg} / \mathrm{m}^{3}\right)$. Sedangkan pada EEI $\left(-50^{\circ}\right)$ nilai batas antara serpih dan gamping adalah $24 \times 10^{9}\left(\mathrm{~kg} . \mathrm{m}^{-}\right.$ $\left.{ }^{2} \cdot \mathrm{s}^{-1}\right)$. Impedansi $\mathrm{S}$ dan EEI $\left(-30^{0}\right)$ termasuk indikator litologi yang baik karena nilai batas $Z_{s}$ untuk serpih dan gamping tidak terlalu tumpang tindih (overlap). Nilai batas impedansi $S$ untuk serpih dan gamping adalah $2 \times 10^{6}\left(\mathrm{~kg} \cdot \mathrm{m}^{-2} \cdot \mathrm{s}^{-1}\right)$ sedangkan pada EEI ($\left.30^{0}\right)$ nilai batas antara serpih dan gamping berada pada nilai $26 \times 10^{9}\left(\mathrm{~kg} \cdot \mathrm{m}^{-2} \cdot \mathrm{s}^{-1}\right)$.

Berdasarkan analisis hasil inversi parameter petrofisika LMR dan EEI untuk identifikasi litologi dan fluida diketahui bahwa daerah prospek yang merupakan akumulasi hidrokarbon (gas) berada pada bagian atas karbonat reff di sekitar waktu 600 ms pada arah NW. Daerah prospek yang merupakan reservoar karbonat dengan akumulasi gas tersebut berada antara CDP 4253 sampai 4301. 


\section{DAFTAR PUSTAKA}

Aina, Z. (2017). Karakterisasi Reservoir Dengan Menggunakan Inversi Simultan Dan Analisis LambdaMu-Rho Untuk Mengidentifikasi Persebaran Zona Potensial Reservoir Karbonat Formasi Baturaja Lapangan "Sukses" Cekungan Sumatra Selatan (Sarjana, Universitas Brawijaya). Retrieved from http://repository.ub.ac.id/4029/

Connolly, P. A. (2010). Robust workflows for seismic reservoir characterization: SEG Distinguished Lecture.

Goodway, B., Chen, T., \& Downton, J. (1997). Improved AVO fluid detection and lithology discrimination using Lamé petrophysical parameters \& fluid stack?, from P and S inversions. In SEG Technical Program Expanded Abstracts. SEG Technical Program Expanded Abstracts 1997 (Vols. 1-0, pp. 183-186). https://doi.org/10.1190/1.1885795

Harun, M. R., Sandria, L. A., Ilhami, A. S., Sukmatiawan, A., \& Razi, M. (2013). Sandstone Reservoir Distribution of Cibulakan Formation Using Seismic Inversion Method: Extended Elastic Impedance (EEI), in Cemara Field, North West Java Basin. Indonesian Petroleum Association (IPA) 13, G-075.

Hermawan, A. D. (2010). Inversi AVO Simultan dan Analisa Lambda Mu Rho untuk Mengidentifikasi Litologi dan Jenis Fluida: Studi Kasus Lapangan Penobscot Canada (Thesis). Bandung, ITB Bandung.

Jayadi, H. (2016). Identifikasi Persebaran Litologi Reservoar Batupasir Menggunakan Analisis Seismik Inversi Impedansi Elastik Di Lapangan Najlaa Formasi Cibulakan Cekungan Jawa Barat Utara. Jurnal Fisika: Fisika Sains dan Aplikasinya, 1 (2), 99-106.

Rutherford, S. R., \& Williams, R. H. (1989). Amplitude-versus-offset variations in gas sands. GEOPHYSICS, 54(6), 680-688. https://doi.org/10.1190/1.1442696

Sumirah. (2007). Deteksi Reservoar Gas Menggunakan Analisis AVo dan Inversi Lambda—Rho dan Tau Phi Data Seismik 3D (Studi Kasus di PT. Pertamina DOH JBB Cirebon) (Skripsi). UGM.

Whitcombe, D. N., Connolly, P. A., Reagan, R. L., \& Redshaw, T. C. (2002). Extended elastic impedance for fluid and lithology prediction. Geophysics, 67(1), 63-67. 